\title{
Effect of seed priming, nitrogen levels and moisture regimes on yield and yield components of wheat
}

Imranuddin ${ }^{1 *}$, Muhammad Arif ${ }^{1}$, Shah Khalid ${ }^{1}$, Nadia $^{1}$, Saddamullah ${ }^{2}$, Muhammad Idrees ${ }^{3}$ and Muhammad $\mathrm{Amir}^{3}$

1. Department of Agronomy, The University of Agriculture, Peshawar-Pakistan

2. Department of Horticulture, The University of Agriculture, Peshawar-Pakistan

3. Amir Muhammad Khan Campus, Mardan-Pakistan

*Corresponding author's email: imranuddin230@yahoo.com

Citation

Imranuddin, Muhammad Arif, Shah Khalid, Nadia, Saddamullah, Muhammad Idrees and Muhammad Amir. Effect of seed priming, nitrogen levels and moisture regimes on yield and yield components of wheat. Pure and Applied Biology. Vol. 6, Issue 1, pp369-377. http://dx.doi.org/10.19045/bspab.2017.60036

\begin{tabular}{llll}
\hline \hline Received: 13/12/2016 & Revised: 28/02/2017 & Accepted: 02/03/2017 & Online First: 03/03/2017 \\
\hline \hline
\end{tabular}

\section{Abstract}

The experiment was layout at the Agronomy research farm, The University of Agriculture, Peshawar, Pakistan, in winter season 2015-16, to study the effect of moisture regimes, seed priming and nitrogen levels on yield and yield components of wheat. The experiment was consist of three factors i.e. moisture regimes (low, and high), seed priming (dry seed, water soaked seed and P-primed seed) and $\mathrm{N}$ levels (0,60, and $\left.120 \mathrm{~kg} \mathrm{ha}^{-1}\right)$. The results indicated that higher moisture regime gives higher number of spike $\mathrm{m}^{-2}$ (332), and thousand grain weight (45g), while in case of $\mathrm{N}$-levels more spike $\mathrm{m}^{-2}$ (343), grains spike $^{-1}$ (49.20), thousand weight (46g), biological yield (10678 $\left.\mathrm{kg} \mathrm{ha}^{-1}\right)$ and grain yield $\left(4433 \mathrm{~kg} \mathrm{ha}^{-1}\right)$ ware recorded at $120 \mathrm{~N} \mathrm{~kg} \mathrm{ha}^{-1}$. In case of priming P-primed seed gives higher spike $\mathrm{m}^{-2}$, grains spike $^{-1}$ (49.4), 1000 grains weight (45.4g), biological (9654 $\mathrm{kg} \mathrm{ha}^{-1}$ ) and grain yield (4032 $\left.\mathrm{kg} \mathrm{ha}^{-1}\right)$ followed by water soaked seeds.

Keywords: Seed priming; Wheat; Moisture regimes; Nitrogen

\section{Introduction}

Wheat (Triticum aestivum L.) is the major crop among cereals in the world. It is the basic food of Pakistan and provides about 73 $\%$ calories and $12 \%$ protein [1]. Wheat is also used for livestock and poultry feed. In Pakistan wheat is cultivated both in irrigated and barani areas. The total area occupied by wheat during 2014-15 in Pakistan was 9046 thousand ha, which produced 25032.9 thousand tones food grain, while in KP the total area occupied by wheat was 769.5 thousand ha, Average yield of wheat in Khyber Pakhtunkhwa (KP) is around 1550 $\mathrm{kg}$ ha-1, which is half of the national average [2]. Punjab is the leading producer of wheat. In KP, more wheat is grown in barani $(61 \%)$ than in irrigated area $(39 \%)$. Besides grain, wheat straw (bhossa) is also used as roughage for livestock.

Seed priming comprises the soaking of seed in water or any chemical or nutrient solution. Due to seed priming a rapid brick down of endosperm occur due to which seed germinate rapidly because priming accelerate the function of enzymes. Due to these processes the seed germinate earlier than dry seed [3]. Priming has a deep effect 
on the quality and yield of wheat. To achieve high quality yield for it vigor and viability of seed is essential. Seed priming improve the vigor and uniformity of germination [4]. Many methods have been used for the seed priming for the purpose to enhance its germination and seedling growth of many crops [5]. For wheat seed priming water is also used as a good medium [6]. Primed seed of wheat with $\mathrm{P}$ increase emergence $\mathrm{m}^{-2}$, tiller $\mathrm{m}^{-2}$, grains spike $^{-1}$, thousand grain weight and grain yield as compared to dry seed [7]. Seed priming with $\mathrm{P}$ improves emergence and seedling growth with regard to untreated seed and showed that water and nutrient can also be used for the priming purpose to increase emergence and early seedling growth of maize [8].

The use of nitrogen fertilizers increased 100 fold over the last 100 years to improve grain yield and protein content [9]. $\mathrm{N}$ fertilization increased wheat biomass [10], yield, [11] and protein content. In fact, nitrogen is a constitutive component of chlorophyll and proteins affecting photosynthesis process. The wheat needs of nitrogen is a complex trait depending on genotypes, years, sites, stage of development, soil type, tillage methods, crop rotation and amount and type of nitrogen fertilizer [12]. The sources of chemical fertilizer have a significant role in nutrients availability and crop productivity. The NH4-N promoted more leaf and stem growth than NO3-N in wheat but did not affect the grain yield [13].

On world basis nitrogen application is round about 80 million tones mostly it is applied in developing states and also in developed countries [9]. Nitrogen is the most limiting nutrient for wheat production [10]. Developing countries trying to supply food for increasing population for this purpose they applying more and more fertilizers. In 2020 the world population will be more than eight billion [11]. However, the fertilizer $\mathrm{N}$ efficiency tend to be low in this system [12]. The role of nitrogen in crop life is important. Nitrogen is one of the most important nutrients which is required to plants in large amount. Balance uses of nitrogen improve vigorous vegetative growth and deep green color .Nitrogen is the most limiting nutrient .Its demand and consumption increasing with the passage of time [13].

The soil and climatic conditions of Pakistan are favorable for wheat and barley, but their yield is still very low as compared to other leading countries. Besides other factors, time and amount of irrigation are two important factors upon which production of a bumper crop depend in irrigated areas. Irrigation is needed in many areas of the country for good crop growth and proper grain development as rainfall is inadequate and erratic throughout the country. On the basis of water requirement cereals have two critical stages at which deficiency of water greatly reduce yield i.e. from adventitious roots to the tillering milk stage. Wheat should be irrigated at adventitious roots development, tillering, spike emergence, anthesis milk stage and other than this it should be irrigated when it need and on water availability [14].

In this experiment we determined the influence of treated seed on emergence, plant growth and yield wheat at two contrasting seedbed moisture condition and available nitrogen.

\section{Materials and methods}

The experiment was conducted at Agronomy research farm, The University of Agriculture Peshawar in winter 2015-2016, to study the response of seed priming, nitrogen and soil moisture regimes on yield components and overall wheat yield. The experiment consisted of three factors i.e. moisture regimes (Low and High), seed priming (dry seed, water soaked, seed primed with $0.2 \% \mathrm{P}$ solution) and nitrogen levels $\left(0,60,120 \mathrm{~kg} \mathrm{ha}^{-1}\right)$. Two separate 
experiments were conducted in RCBD, one under high moisture seedbed condition and other under low moisture seedbed condition. Date of sowing was $25^{\text {th }}$ November 2015. Treatment combination of seed priming and $\mathrm{N}$ levels were kept in both experiments with three replications. Low moisture plots were irrigated two weeks before sowing while high moisture plots were irrigated a week before sowing. Both low and high moisture plots were not irrigated till $40^{\text {th }}$ day after sowing. Soil moisture of both low and high moisture regimes were 23 and $30 \%$, respectively at the time of sowing of the crop. Wheat variety Siran-2010 was cultivated at the rate of $120 \mathrm{~kg} \mathrm{ha}^{-1}$ in a subplot size of $4.8 \mathrm{~m}$ by $3 \mathrm{~m}$ having 16 rows 3 meter long and row to row distance was 30 $\mathrm{cm}$.

Nitrogen was applied in three split levels, one third each at sowing, tillering and boot stages. Seed priming was consisted of dry seed, water soaked seed and seed primed in $0.2 \% \mathrm{P}$ solution. $\mathrm{KH}_{2} \mathrm{PO}_{4}$ was used as source of P. For primed seeds, $180 \mathrm{~g}$ of seed plot $^{-1}$ was put in polyethylene bags having pores and then were treated with water for 12 hours in either distilled water or in a $0.2 \%$ aqueous solution of P. After priming, bags were removed, drained and then surface dried in shade for around half an hour to facilitate clump-free sowing. Phosphorous at the rate of $90 \mathrm{~kg} \mathrm{ha}^{-1}$ was applied at sowing time. Sources of phosphorous and $\mathrm{N}$ were SSP and urea, respectively. All the standard agronomic practices were uniformly adopted for the experiment.

Data ware recorded on the following parameters

\section{Early plant growth (Fresh shoot weight)}

For recording data on early plant growth, randomly selected five tillers in each plot were cut at the base and data on fresh shoot weight, plant height and number of leaves at
$14,21,28,35,42$ and 49 days after sowing were recorded.

Spike $\mathbf{m}^{-2}$

Data on spikes $\mathrm{m}^{-2}$ was determined by counting the spikes in three randomly rows of one meter length and then converted into spikes $\mathrm{m}^{-2}$.

Grains spike ${ }^{-1}$

Grains from five randomly selected spikes were obtained by hand threshing and were counted and converted into average number of grains spike ${ }^{-1}$.

\section{Thousand grain weight (g)}

Thousand grains were counted that were randomly picked from each sub plot and weighed with a digital balance.

\section{Biological yield ( $\mathrm{kg} \mathrm{ha}^{-1}$ )}

Four central rows were harvested in each subplot and sun dried and bundles were weighed and its biological yield was converted into $\mathrm{kg} \mathrm{ha}^{-1}$.

\section{Grain yield (kg ha-1)}

Small wheat thresher was used for threshing the biological yield taken from four central rows in each sub plot. After threshing the grains were weighed by balance and from it yield $\mathrm{kg} \mathrm{ha}^{-1}$ was calculated.

\section{Harvest index (\%)}

Harvest index was calculated as the ratio of grain yield to the total biological yield.

\section{Statistical analysis}

Data were statistically analyzed using the procedure suitable for RCBD design with significant F-value. The least significant difference (LSD) test was applied for the comparison of treatments means at $5 \%$ level of probability steel et al. [15].

\section{Results and discussion}

\section{Fresh shoot weight}

Data pertaining fresh shoot weight of wheat are given in Table 1. Analysis of the data showed that the effects of moisture, $\mathrm{N}$ levels and seed priming were not significant, while fresh shoot weight significantly varied during different weeks (W). Similarly, all interactions were found non-significant. 
Fresh shoot weight significantly increased with time interval. It increased from $0.03 \mathrm{~g}$ to $0.06 \mathrm{~g}(88 \%)$ during first week. During second week, it increased $58 \%$ from $0.06 \mathrm{~g}$ to $0.10 \mathrm{~g}$. In week third, it increased from $0.10 \mathrm{~g}$ to $0.12 \mathrm{~g}(16 \%)$. It increased from $0.12 \mathrm{~g}$ to $0.20 \mathrm{~g}(63 \%)$ during week four. Similarly, in week five, it increased from $0.20 \mathrm{~g}$ to $0.28 \mathrm{~g}(39 \%)$. Similar views by Fluegel and Jhonson [16] concluded that higher irrigation application have a positive effect on fresh shoot biomass of wheat at seedling stage. Results are dissimilar with Noureldin et al. [17] who reported that unit area biomass increased with increasing $\mathrm{N}$ level. Similar views by Afzal et al. [18] found that seed priming treatments significantly improved fresh seedling weight.

Table 1. Fresh shoot weight tiller ${ }^{-1}(\mathrm{~g})$, Spikes $\mathbf{m}^{-2}$, Grains spike ${ }^{-1}$ and 1000 grains weight (g) of wheat as influenced by moisture, $\mathrm{N}$ levels, seed priming

\begin{tabular}{|c|c|c|c|c|}
\hline Treatments & $\begin{array}{l}\text { Fresh shoot } \\
\text { weight (g) }\end{array}$ & Spikes m-2 & Grains spike $^{-1}$ & $\begin{array}{l}\text { Thousand grain } \\
\text { weight (g) }\end{array}$ \\
\hline Low & 0.14 & $294 \mathrm{~b}$ & 47.6 & $43 \mathrm{~b}$ \\
\hline High & 0.13 & $332 \mathrm{a}$ & 48.2 & $45 \mathrm{a}$ \\
\hline Significance level & ns & $* *$ & ns & $*$ \\
\hline \multicolumn{5}{|l|}{ Nitrogen $\left(\mathrm{kg} \mathrm{ha}^{-1}\right)$} \\
\hline 0 & 0.13 & $289 \mathrm{~b}$ & $45.8 \mathrm{~b}$ & $42 \mathrm{~b}$ \\
\hline 60 & 0.14 & $306 \mathrm{~b}$ & $48.7 \mathrm{a}$ & $44 \mathrm{ab}$ \\
\hline 120 & 0.13 & $343 \mathrm{a}$ & $49.20 \mathrm{a}$ & $46 \mathrm{a}$ \\
\hline LSD & ns & 26.89 & 2.15 & 2.28 \\
\hline \multicolumn{5}{|l|}{ Seed Priming } \\
\hline Dry seed & 0.13 & $293 \mathrm{~b}$ & $46.7 \mathrm{ab}$ & $42.7 \mathrm{~b}$ \\
\hline Water soaked seed & 0.14 & $309 \mathrm{~b}$ & $47.6 \mathrm{a}$ & $43.2 \mathrm{ab}$ \\
\hline P primed seed & 0.13 & $337 \mathrm{a}$ & $49.4 \mathrm{a}$ & $45.4 \mathrm{a}$ \\
\hline LSD & ns & 26.89 & 2.15 & 2.28 \\
\hline \multicolumn{5}{|l|}{ Weeks } \\
\hline 1 & $0.03 \mathrm{e}$ & & & \\
\hline 2 & $0.06 \mathrm{de}$ & & & \\
\hline 3 & $0.10 \mathrm{~cd}$ & & & \\
\hline 4 & $0.12 \mathrm{c}$ & & & \\
\hline 5 & $0.20 \mathrm{~b}$ & & & \\
\hline 6 & $0.28 \mathrm{a}$ & & & \\
\hline LSD & 0.05 & & & \\
\hline
\end{tabular}

Mean values followed by different letters in each category are significantly different at $5 \%$ level of probability using LSD test, $\mathrm{ns}=$ non-significant

\section{Spike $\mathbf{m}^{-2}$}

Data regarding spike $\mathrm{m}^{-2}$ of wheat are given in Table 1. Analysis of the data showed that the effects of moisture, nitrogen and seed priming were significant while all the interactions were not significant. Maximum spike $\mathrm{m}^{-2}$ was recorded for high moisture plots (332) as compared to low moisture plots (294). Nitrogen level increased number of spike $\mathrm{m}^{-2}$. Higher number of spike $\mathrm{m}^{-2}$ were recorded for $120 \mathrm{~kg} \mathrm{~N} \mathrm{ha}{ }^{-1}$ (343) followed by 60 (306) and $0 \mathrm{~kg} \mathrm{ha}^{-1}$ (289). Higher number of spikes were recorded for $\mathrm{P}$ primed seed (337) followed by water 
soaked seed (309) and dry seed (293). Results are supported by Brahma et al. [19] who recorded maximum number of spikes $\mathrm{m}^{-2}$ in frequently irrigated treatments. Similarly, Akhtar [20] found that spikes $\mathrm{m}^{-2}$ significantly increased by increasing levels of $\mathrm{N}$ Harris et al. [21] argued that increase in spikes $\mathrm{m}^{-2}$ due to priming might be due to improved emergence and better seedling growth.

\section{Grains spike ${ }^{-1}$}

Data regarding grains spike $^{-1}$ of wheat are given in Table 1. Analysis of the data revealed that moisture effect on grain spike ${ }^{-1}$ was not significant while the effects of nitrogen levels and seed priming were significant. All the interactions were found non-significant. Higher grains spike ${ }^{-1}$ was recorded for $120 \mathrm{~kg} \mathrm{~N} \mathrm{ha}^{-1}$ (49.2) and $60 \mathrm{~kg}$ $\mathrm{N} \mathrm{ha}{ }^{-1}$ (48.7) as compared to $0 \mathrm{~kg} \mathrm{~N} \mathrm{ha}^{-1}$ (45.8). Seed priming improved grains spike 1. Higher grains spike ${ }^{-1}$ were recorded for $P$ priming treatment (49.4) followed by water soaked (47.6) and dry seed (46.7). Results are not similar with Pandey et al. [22] concluded that in response to irrigation overall grain yield and yield components significantly increased Likewise, Khan et al. [23] found that grains spike ${ }^{-1}$ significantly increased by increasing levels N. Basra et al. [24] and Khan et al. [25] reported that in mung bean grains pod enhanced by treated seeds.

\section{Thousand grain weight (g)}

Data concerned thousand grains weight of wheat are given in Table 1. Data analysis showed that moisture, nitrogen and seed priming positively affected thousand grain weight of wheat. Similarly, all the interactions were not significant. High moisture plots resulted in higher thousand grain weight (45g) as compared to low moisture plots (43g). Thousands grain weight increased with higher level of $\mathrm{N}$. Higher thousand grain weight was obtained at $120 \mathrm{~kg} \mathrm{~N}^{-1}$ (46 g) followed by $\mathrm{N}$ level of 60 (44 g). While lower thousand grain weight was recorded for $0 \mathrm{~kg} \mathrm{~N} \mathrm{ha}^{-1}$ (42 g). Seed priming improved thousand grain weight. Higher thousand grain weight was recorded for $\mathrm{P}$ primed and water soaked seed (45.48 and $43.29 \mathrm{~g}$, respectively). Lower thousand grain weight was recorded for dry seed $(42.7 \mathrm{~g})$. These results are supported by the findings of Jamal [26] who stated that plots received four irrigations gave maximum grain weight and the lowest grain yield by two irrigations. Similar views by Zubair et al. [27] who reported that higher levels of nitrogen increased vegetative growth and more photosynthesis occurred and more photosyntheate were transferred to sink which enhanced grain weight. Likewise, Basra et al. [28] concluded higher grain weight and biomass for primed seeds.

\section{Biological yield ( $\left.\mathrm{kg} \mathrm{ha}^{-\mathbf{1}}\right)$}

Data pertaining biological yield are shown in Table 2. Data analysis revealed that nitrogen levels and seed priming significantly affected biological yield of wheat. The effect of moisture was not positive. Similarly, all the interactions were not positive. Biological yield increased with increasing level of $\mathrm{N}$. Higher biological yield was obtained at $120 \mathrm{~kg} \mathrm{~N} \mathrm{ha}^{-1}$ (10678 $\mathrm{kg} \mathrm{ha}^{-1}$ ) followed by $\mathrm{N}$ level of $60 \mathrm{~kg} \mathrm{~N} \mathrm{ha}^{-1}$ $\left(9515 \mathrm{~kg} \mathrm{ha}^{-1}\right)$. Lesser biological yield (7763 $\mathrm{kg} \mathrm{ha}^{-1}$ ) was obtained at $0 \mathrm{~kg} \mathrm{~N} \mathrm{ha}^{-1}$. Seed priming improved biological yield. Higher biological yield of $9654 \mathrm{~kg} \mathrm{ha}^{-1}$ and $9413 \mathrm{~kg}$ $\mathrm{ha}^{-1}$ was recorded for $\mathrm{P}$ primed seed and water soaked respectively, while dry seed resulted in lower biological yield $(8889 \mathrm{~kg}$ $\left.\mathrm{ha}^{-1}\right)$. These results are dissimilar with Tahmasabi et al. [29] who determined that biological yield increased as number of irrigations increased. The results are in line with Zubair et al. [27] who stated that higher $\mathrm{N}$ levels increased vegetative growth which enhanced biological yield. 
Table 2. Biological yield $\left(\mathrm{kg} \mathrm{ha}^{-1}\right)$, grain yield and harvest index (\%) of wheat as influenced by moisture, $N$ levels and seed priming

\begin{tabular}{|c|c|c|c|}
\hline Moisture & Biological yield $\left(\mathrm{kg} \mathrm{ha}^{-1}\right)$ & Grain yield (kg ha-1) & Harvest index \% \\
\hline Low & 9203 & 3804 & 41.3 \\
\hline High & 9435 & 3933 & 41.7 \\
\hline Significance level & Ns & Ns & Ns \\
\hline \multicolumn{4}{|l|}{ Nitrogen $\left(\mathrm{kg} \mathrm{ha}^{-1}\right)$} \\
\hline 0 & $7763 \mathrm{c}$ & $3160 \mathrm{c}$ & 40.8 \\
\hline 60 & $9515 \mathrm{~b}$ & $4011 b$ & 42.2 \\
\hline 120 & $10678 \mathrm{a}$ & $4433 \mathrm{a}$ & 41.5 \\
\hline LSD & 374.5 & 235.9 & Ns \\
\hline \multicolumn{4}{|l|}{ Seed priming } \\
\hline Dry seed & $8889 \mathrm{~b}$ & $3691 \mathrm{~b}$ & 41.6 \\
\hline Water soaked seed & $9413 \mathrm{a}$ & $3882 \mathrm{ab}$ & 41.1 \\
\hline P primed seed & $9654 \mathrm{a}$ & $4032 \mathrm{a}$ & 41.7 \\
\hline LSD & 374.5 & 235.9 & Ns \\
\hline
\end{tabular}

Mean values followed by different letters in each category are significantly different at

$5 \%$ level of probability using LSD test, ns = non-significant

\section{Grain yield $\left(\mathrm{kg} \mathrm{ha}^{-1}\right)$}

Grain yield data of wheat are given in Table 2. Data analysis revealed that nitrogen levels and seed priming positively influenced wheat grain yield. Moisture and interaction effect was non-significant. With the increase in level of $\mathrm{N}$ yield of grains also increased. Maximum grain yield was obtained at 120 $\mathrm{kg} \mathrm{N} \mathrm{ha}^{-1}\left(4433 \mathrm{~kg} \mathrm{ha}^{-1}\right)$ followed by $\mathrm{N}$ level of $60 \mathrm{~kg} \mathrm{~N} \mathrm{ha}^{-1}\left(4011 \mathrm{~kg} \mathrm{ha}^{-1}\right)$. Minimum grain yield $\left(3160 \mathrm{~kg} \mathrm{ha}^{-1}\right)$ was obtained at 0 $\mathrm{kg} \mathrm{ha}^{-1}$. Seed priming improved grain yield. Maximum grain yield of 4032 and $3882 \mathrm{~kg}$ $\mathrm{ha}^{-1}$ were recorded for $\mathrm{P}$ primed and water soaked seed, respectively. Lower grain yield was recorded for dry seed (3691 kg ha-1). Results are not similar with Pandey et al. [22] who found linear response between number of irrigations and grain yield. Similar views by Marino et al. [30] who determined that $\mathrm{N}$ application increased biomass and grain yield of the crop. Ghosh et al. [31] determined higher grain yield for primed seed as compared to dry seed. Water is also used as a medium for seed priming due to which yield increases. (Harris et al. [32], Rashid et al. [33].

\section{Harvest index (\%)}

Data pertaining to harvest index of wheat are given in Table 2. Obtained data showed that the effects of moisture, nitrogen levels and seed priming were not significant. Similarly, all the interactions were also not significant. Though the effect of moisture was not significant but more harvest index (41.7\%) was recorded for high moisture plots compared to low moisture plots (41.3\%). Higher harvest index was recorded for $60 \mathrm{~kg} \mathrm{~N} \mathrm{ha}{ }^{-1}$ (42.2\%) followed by 120 (41.5\%) and $0 \mathrm{~kg} \mathrm{~N} \mathrm{ha}^{-1}$ (40.8\%). Higher harvest index was obtained for $\mathrm{P}$ primed seed $(41.7 \%)$ followed by dry seed $(41.6 \%)$ and water soaked seed (41.1\%). Results are also in disagreement with Akhtar [20] who stated that harvest index was significantly affected by nitrogen levels. Likewise, Shatab and khan [34] also reported that harvest index increased with P priming.

\section{Conclusion}

High moisture (seedbed) resulted in higher yield and yield components as compared to low moisture seedbed. $\mathrm{N}$ at the rate of 120 $\mathrm{kg} \mathrm{N} \mathrm{ha} \mathrm{N}^{-1}$ produced higher yield and yield components as compared to other levels. 
Phosphorous primed seed resulted in maximum grain yield and yield components as compared to water soaked and dry seed.

\section{Recommendation}

High moisture seedbeds are recommended to the farmers for higher yield and yield components of wheat. Fertilizer N application levels of $120 \mathrm{~kg} \mathrm{ha}^{-1}$ in split dose is recommended to the farmers on the basis of yield performance. $\mathrm{P}$ priming is recommended to the farmers on the basis of good crop stand and yield performance.

\section{Authors' contributions}

Conceived and designed the experiments: I Uddin, M Arif, Performed the experiments: I Uddin, Analyzed the data: M Arif, Contributed reagents/ materials/ analysis tools: S Khalid, Nadia, M Aamir S Ullah \& M Idrees, Wrote the paper: I Uddin.

\section{Acknowledgment}

Special thanks to Dr. Muhammad Arif, Associate Professor, The University of Peshawar, for statistical analysis and Higher Education, commission for financially support.

\section{References}

1. Mahmood SU, Bashir MH, Abrar M, Sabri MA \& Khan MA (2013). Appraising the Changes in the Nutritional Value of Stored Wheat, Triticum aestivum L. Infested with Acarid Mite, Rhizoglyphus tritici (Acari: Acaridae). Pak J Zool 45: 12571261.

2. MNFSR (2014). Ministry of National Food Security and Research, Government of Pakistan-Islamabad. pp. 1-3.

3. Asgedon H \& Becker M (2001). Effects of seed priming with nutrient solutions on germination, seedling growth and weed competitiveness of cereals in Eritrea. In proc. $M$ Deutscher Tropentag Univ. of Bonn \& ATSAF. Marg far Pub Pressm Wieckersheim pp.282.
4. Rowse HR (1995). Drum priming -A nonosmotic method of priming seed. Seed Sci Tec 24: 281-294.

5. Sharifi RS \& Khavazi K (2011). Effects of seed priming with plant Growth Promoting Rhizobacteria (PGPR) on yield and yield attribute of maize (Zea mays L.) hybrids," J Food Agri and Env vol. 9, no. 3-4, pp. 496-500.

6. Harris D, Raghuwanshi BS, Ganwar JS, Singh SC, Joshi KD, Rashid A \& Hollington PA (2001). Participatory evolution by farmers of on form seed priming in wheat in India, Nepal and Pakistan. Exp Agric 37: 403-415.

7. Khan S \& Khalil SK (2007). Effect of seed priming with phosphorus concentration and application rates on wheat. M.Sc (Hons) thesis, Dept. of Agronomy, NWFP Agricultural University Peshawar.

8. Arif, M., Ali, S. Shah, A. Javed N. and Rashid. A. 2005. Seed priming maize for improving emergence and seedling growth. Sarhad J. Agric. 21(4): 439441.

9. López-Bellido RJ, Castillo JE \& LópezBellido L (2008) Comparative response of bread and durum wheat genotypes to nitrogen fertilizer in a rainfed Mediterranean environment: soil nitrate and $\mathrm{N}$ uptake and efficiency, Nutr Cycl Agroecosyst 80: pp. 121-130

10. Boukef S, Karmous CY, Trifa Y \& Rezgui S (2013) Nitrogen sources effect on durum wheat (Triticum durum desf.) yield and yield components under Mediterranean rainfed environment. Canadian $J$ of Plant Breeding 1(1): pp. 15-22.

11. Tariq Jan M, Jamal Khan M, Khan A, Arif M, Saeed D \& Afridi MZ (2011). Improving wheat productivity through source and timing of nitrogen fertilization. Pak J Bot 43(2): pp. 905914. 
12. Stewart WM, Dibb DW, Johnston AE \& Smyth TJ (2005). The contribution of commercial fertilizer nutrients to food production. Agron J 97 pp. 1-6.

13. Tranavicienè T, Siksnianiene JB, Urbonaviciute A, Vaguseviciene I, Samuoliene G, Duchovskis P \& Sliesaravicius A (2007) Effects of nitrogen fertilizers on wheat photosynthetic pigment and carbohydrate contents, Biologija 53(4): pp. 80-84.

14. Paigham S (1994). In book Crop Production edt by Shafi Nazir, Elena Bashir, Robyn Bantel P: 240-241, NBP. Islamabad.

15. Steel RGD, Torrie JH \& Dickey D (1997). Principles and procedures of statistics: A Biometrics Approach, 2nd ed. McGraw-Hill, New York.

16. Fluegel \& Jhonson. 2001. The effect of irrigation levels and wheat resistance to the Russian wheat aphid, Diuraphis noxia (Homoptera: Aphididae). J Kans Entomol Soc 74 (1): 49-55.

17. Ki Noureldin NA, Saudy HS, Ashmawy F \& Saed HM (2013). Grain yield response index of bread wheat cultivars as influenced by nitrogen levels. Annals of Agricultural Science 58: 147-152.

18. Afzal A, Khalil SK, Abudullah \& Khan A (2005). Effect of polyethylene Glycolconcentrations and duration on mung been. Sarhad J Agric 21: 171175.

19. Brahma R, Janawade AD \& Palled YB (2006). Effect of irrigation schedules on Growth, Yield and Economics of wheat (cv. DWD-106). Karnataka J Agric Sci 20(1): 6-9.

20. Akhtar MM (2001). Effect of varying levels of nitrogen on growth and yield performance of two new wheat cultivars. M.Sc (Hons) thesis,
Deparment of Agronomy, Uni of Agri

Faisalabad pp 84-86.

21. Harris D, Rashid A, Arif M \& Younas M (2004). Alleviating micro nutrient deficiencies in alkaline soils of North West Frontier Province of Pakistan: on form seed priming with zinc and wheat and chickpea. An international workshop on Agricultural Strategies to Reduce Micronutrient Problems in Mountains and Other Marginal Areas in South and S. E. Asia. Kathmandu. Nepal Agricultural Research Council.

22. Pandy RK, Maranville JW \& Chetima MM (2001). Tropical wheat response to irrigation and nitrogen in sahelian environment. Eur J Agron 15 (2): 93105. AN: 490QC-0003.

23. Khan MA, Jan N, Sultana Q, Ahmad SR \& Rahman A (2006). Effect of differenmt organic materials and chemical fertilizer on the yield of wheat and physical properties of soil. Sarhad J Agric 22(3):38-44.

24. Basra SMA, Ehsanullah, Warraich, EA, Cheema MA \& Afzal I (2003). Effect of storage on growth and yield of primed canola (Barassica napus L) seeds. Int J Agric Bio 117-120.

25. Khan A, khalil SK, Khan S \& Afzal A (2005). Priming effects crop stand of mung bean. Sarhad J Agric 21(4): 535538.

26. Jamal A (2000). Effect of irrigation starting with different readily available soil water on winter wheat yield in Karaj area. Iranian-Journal of Agricultural Sciences 31(1): 111-118.

27. Zubair M, Bakhat J, Shafi M \& Khan MJ (2009). Effect of methods and levels of nitrogen application on wheat varieties. Ms.c (Hons) Thesis, Department of Agronomy, Agriculture University Peshawar 43-44 p.

28. Basra SMA, Farooq \& khaliq A (2003). Comparative study of pre- sowing seed 
enhancement treatments in fine rice (oryza sativa L.). Pak J Life Soc Sci 1: 5-9.

29. Tahmasabi R \& Farad H (2000). Effect of irrigation starting with different readily available soil water on winter wheat yield in Karaj area. IranianJournal of Agricultural Sciences 31(1): 111-118.

30. Marino S, Tognetti R \& Alvino A (2009). Crop yield and grain quality of emmer populations grown in central Italy, as affected by nitrogen fertilization. European Journal of Agronomy 31: 233-240.

31. Ghosh DC, Mandal BP \& Malik GC (1997). Growth and yield of wheat (Triticum aestivum L.) as influenced by fertility level and seed- soaking agro-chemical. Ind J Agric Sci 67(4): 144-146.

32. Harris D, Tripathi RS \& Joshi A (2000). On-farm seed priming to improve crop establishment and yield in directseeded rice, in IRRI: Inter. Workshop on Dry-seeded Rice Tech.

33. Rashid A, Harris D, Hollington PA \& Khattak RA (2002). On-farm seed priming: a key technology for improving the livelihoods of resourcepoor parmers on saline lands. Prospects for saline Agric 6: 423-431.

34. Shatab \& Khan S (2007). The effect of priming and $\mathrm{P}$ levels on wheat crop. MSc (hons) thesis, Deptt. of Agronomy, Agri Uni Peshawar pp. 5354. 